УДК 378.4

\title{
ФОРМЫ ОРГАНИЗАЦИИ НАУЧНОГО ВЗАИМОДЕЙСТВИЯ В СОВРЕМЕННОМ УНИВЕРСИТЕТЕ
}

\section{Ряписов Николай Александрович} доктор экономических наук, профессор, первый проректор

Ряписова Алевтина Геннадьевна кандидат педагогических наук, доцент заведующий кафедрой психологии и педагогики ФГБОУ ВО «Новосибирский государственный педагогический университет»

Аннотация: в статье актуализируется необходимость осуществления научно-исследовательской деятельности в университете; представлено определение научной коммуникации и охарактеризованы сущность и специфика организации разнообразных форм научного взаимодействия - как массовых научных мероприятий, так и групповых форм взаимодействия участников. Подчеркивается необходимость ориентации на целевую аудиторию участников и задачи проведения научных мероприятий для обеспечения их эффективности.

Ключевые слова: университет, научная коммуникация, конференция, научная школа, форум, симпозиум, конгресс, пленарное заседание, групповые формы работы.

\section{FORMS OF ORGANIZATION OF SCIENTIFIC INTERACTION IN A MODERN UNIVERSITY}

\section{Ryapisov Nikolai Alexandrovich Ryapisova Alevtina Gennadievna}

\begin{abstract}
: the article actualizes the need to carry out research activities at the university; presents the definition of scientific communication and describes the nature and specifics of the organization of various forms of scientific interaction both mass scientific events and group forms of interaction of participants. The need to focus on the target audience of participants and the tasks of conducting scientific events to ensure their effectiveness is emphasized.
\end{abstract}

Key words: university, scientific communication, conference, scientific school, forum, symposium, congress, plenary session, group forms of work. 
Университет, в отличие от других образовательных организаций высшего образования - института и академии - по определению является научноучебным учреждением, в котором выполняются фундаментальные и прикладные научные исследования по широкому спектру наук. Более 60\% профессорско-преподавательского состава должны иметь ученые степени. Университетское образование сочетает обучение и научную деятельность студентов - в формате курсовых, выпускных квалификационных работ. В современном университете учебные занятия нередко проходят в различных формах научного взаимодействия (научно-практические конференции, научные школы, панельные дискуссии, проектные сессии и др.).

Практика научной коммуникации начала складываться в Европе в XVII веке и формировалась на основе личных связей и отношений. К XIX-XX веков наблюдается рост интереса широких масс к научным достижениям и науке как таковой. Закономерно, появились новые формы взаимодействия между субъектами в рамках научного сообщества [1].

Термин научная коммуникация понимается как процессы и формы взаимодействия науки и общества, популяризации научного результата, представления результатов исследований. Поскольку научная коммуникация ориентирована на различные целевые аудитории, поскольку в их работе принимают участие не только ученые, но и представители органов государственной власти, бизнес структур, общественности, студенты и др., то и необходимы разнообразные формы ее организации, которые были бы ориентированы на особенности субъектов, адекватны задачам взаимодействия для обеспечения эффективности решения специфических задач, стоящих перед наукой и обществом.

Развитие научного знания закономерно требует инновационных форм его воплощения [2]. В современном университете приняты следующие формы организации научного взаимодействия: научно-практическая конференция, научная школа, форум, симпозиум, конгресс. Каждая форма предполагает организацию специфической деятельности, поэтому для соблюдения законов жанра необходимо осознать уникальные особенности разнообразных форм научной коммуникации. Рассмотрим их подробнее.

Научно-практическая конференция - форма проведения научнопрактического собрания для обсуждения определённых тем; как правило, включает пленарное заседание, на котором с основными докладами выступают наиболее значимые лица, и секционные мероприятия в различных групповых 
формах взаимодействия; количество участников может достигать тысячи человек, а длительность мероприятия может составлять несколько дней; по итогам работы принимаются определенные решения и рекомендации для участников.

Форум - название имеет латинское происхождение и в дословном переводе означает «рыночная площадь»; можно трактовать как массовое представительное собрание, проводимое для обмена мнениями и обозначения актуальных проблем, на котором все участники выступают на равных, где каждый волен высказывать свои мысли или несогласие с мнением другого, важен сам процесс общения и обсуждения.

Симпозиум - название происходит от древнегреческого слова, в переводе означающего «пиршество». В современной интерпретации понимается как периодически и регулярно организуемое научное собрание с участием представителей разных стран; посвящается темам, в отношении которых имеется значительное количество точек зрения; в ходе проведения предоставляется слово сторонникам различных позиций; участники заранее представляют в организационный комитет темы и краткие изложения своих докладов, и после их согласования и утверждения они включаются в программу симпозиума; мероприятие проводится по заранее спланированному графику, включающему в себя состав и регламент всех выступлений.

Конгресс (от лат. - «сходиться вместе») - высшая форма научного сотрудничества международного уровня, наиболее масштабное и статусное мероприятие для представления достижений и заметных результатов в конкретной области; в качестве приглашенных докладчиков принимают участие лидеры, причем, не только ученые, но и представители бизнеса, государственной власти.

В справочных изданиях можно найти три разных значения научной школы. Прежде всего, это - форма организации образовательного процесса, а также научное направление или исследовательский коллектив. Однако опыт организации научных школ показывает, что в реальной практике все эти значения интегрируются. Главное назначение проведения научных школ привлечение единомышленников, обучение последователей и приобщение их к научным идеям для обеспечения преемственности в научно-исследовательской деятельности.

Массовые научные мероприятия традиционно включают в программу пленарные заседания и лекционные занятия, а также разнообразные групповые 
формы научно-образовательного взаимодействия [3], например, такие как панельная дискуссия, круглый стол, аналитическая или стратегическая сессия, баркемп, форсайт, кейс-стади, бэкграунд, мастер-класс, творческая встреча, образовательный трек и другие. Для их организации и проведения необходимо точно знать специфические особенности.

Панельная дискуссия - одна из форм дискуссии, на которой несколько приглашенных экспертов выступают с кратким сообщением, излагая аудитории свои позиции, после чего модератор предлагает остальным участникам задавать вопросы.

Круглый стол - форма организации публичного обсуждения актуальных вопросов, чаще - практического характера с целью обобщить идеи и мнения относительно обсуждаемой проблемы, но не служит инструментом выработки конкретных решений.

Баркемп (от англ. barcamp) - мероприятие без жесткой структуры и регламента («анти-конференция»), при котором нет специально приглашенных докладчиков, а каждый становится не только участником, но и организатором, может выступить с новой идеей, предоставить свои материалы для обсуждения в рамках направления конференции; при проведении баркемпа нет слушателей, каждый участник проявляет свой интерес, помогает выступающим (развивает их идеи, предлагает альтернативы, приводит аналогии), участвует в дискуссии; это формат взаимодействия компетентных людей с похожими интересами, в ходе которого происходит обмен знаниями и опытом, обсуждаются актуальные проблемы в зоне профессионального общения, осуществляется поиск самых интересных идей, устанавливаются и расширяются контакты.

Кейс-стади (от англ. case-study, case - «случай, ситуация», study «изучение, обучение») - форма организации группового взаимодействия, в ходе которой происходит анализ реальной жизненной ситуации; для ее решения необходимо усвоить комплекс теоретических знаний и выработать оптимальное эффективное решение.

Форсайт (от англ. foresight - «видение будущего») - форма группового взаимодействия по поводу образа будущего. Участники оценивают перспективы и их риски, обсуждают необходимые условия и проектируют свою деятельность таким образом, чтобы усилить положительные тренды, увеличить вероятность желаемых событий и устранить или снизить отрицательные, нежелательные явления. В результате создается карта будущего, т.е. визуализация с помощью образов и схем, позволяющая увидеть различные способы и пути достижения желаемого результата. 
Мастер-класс (от англ. master - искусный специалист, мастер и class курс обучения) - форма организации краткосрочного курса повышения квалификации, который проводит известный специалист для начинающих; по целям: обучающий (овладение изучаемым материалом) и демонстрационный (демонстрация идей, возможностей или достижений в обозначенной сфере).

Творческая встреча (видеовстреча) - собрание, устраиваемое с целью знакомства с автором и презентации его работ; как правило, включает организацию беседы и тематическое обсуждение в кругу заинтересованных и компетентных людей.

Образовательный трек - мероприятие с гибкой программой, учитывающей образовательные запросы участников.

Бэкграунд (от англ. background) - краткая форма изложения основной информации в качестве дополнения, поддержки, иллюстрации «на фоне» главных участников; обычно - выступления педагогов-практиков или магистрантов, расширяющие представления о ключевых идеях докладов.

Как правило, на завершающем этапе научного взаимодействия применяются различные способы организации рефлексии (от лат. reflexio «обращение назад») для анализа, осмысления, переосмысления процессов и результатов собственной деятельности с целью фиксации качества ее итогов и повышения эффективности в дальнейшем.

\section{Список литературы}

1. Руди А.Ш. Формы и особенности научных коммуникаций // Исторические, философские, политические и юридические науки, культурология и искусствоведение. Вопросы теории и практики. 2016. №4-2 (66). С. 136-138.

2. Ряписова А.Г. Инновационные формы организации образовательного процесса // Вестник педагогических инноваций. 2017. № 1 (45). С. 5-14.

3. Зальвинова О.Б. Формы и методы групповой работы с учащимися // Современные исследования. 2018. № 4 (08). С. 71-73.

(C) Н.А. Ряписов, А.Г. Ряписова, 2021 